are chapters by the editor, Dr. Jolles, and by twenty. three other authors from a large number of industries and universities. The book is divided into seven sections: the manufacture and physical and chemical properties of elemental bromine; inorganic bromine compounds; organic bromine compounds-this deals mainly with methods of bromination and related reactions, for example, addition, substitution and elimination; radioactive bromine and bromine in radiation chemistry; biological aspects of bromine and its compounds; industrial applications; and analytical chemistry of bromine and its compounds (including applications of most types of spectroscopy).

Such a multitude of topics are covered that an exhaustive appraisal would require a reviewer of exceptionally catholic tastes, but it is clear that the editor and his coauthors have produced an important reference work, and that they have largely succeeded in one of their objectives which was to summarize existing knowledge of bromine and its compounds. They also hope to stimulate the use of bromine and its compounds as an alternative to chlorine and its compounds, particularly in industrial processes, and the book will be invaluable to anyone considering this.

The cost and contents are such that the book will be bought by few individuals although all libraries should consider it an essential aequisition. This raises two points. At present the book stands alone: its value would be enhanced if it were accompanied by companion volumes on the other halogens. The direct orientation towards bromine chemistry also conflicts to some extent with the comparative approach which is so useful in dealing with the properties of the halogens.

Finally, a good point-the book is relatively free from errors-and a criticism-the references given to the thermodynamic properties of bromine are obsolete.

E. WhitTLL

\section{TASMANIAN JOURNAL}

\section{Friendly Mission}

The Tasmanian Journals and Papers of George Augustus Robinson, 1829-1834. Edited by N. J. B. Plomley. Pp. xiii $+1074+17$ plates. (Hobart: Tasmanian Historical Research Association, 1966.) A.126s.

Although the aboriginal tribes of Tasmania were in contact with Europeans for some decades before they finally became extinct (approximately from 1770 to 1870 ), there is nevertheless very little worthwhile information about them. Before the publication of the book under review, much of the information was provided by the records of French explorers during the late eighteenth and early nineteenth centuries. The Robinson papers, missing for many years, therefore provide a large additional source of information on these people.

George Augustus Robinson began his work among the aboriginals in very troubled times, and was successively conciliator of the Tasmanian tribes, commandant at the Flinders Island aboriginal settlement, and chief protector of the aborigines at Port Phillip. During this time he kept various records of his work with these people, most important being his field journals. The book is mainly concerned with the period 1829-1834, giving a day by day account of his experiences with the tribes-and in the case of some of them, his information is all that we have.

The mass of writing left by Robinson was by no means orderly, and the editor has clearly been to great pains to sort and cross-check names, localities and other information. Additional hazards for him were poor writing and early nineteenth century punctuation (or lack of it). Plomley is to be congratulated on his careful and scholarly editing, and in lacing the journals together so well with the many additional notes.
The book is of value not only as a source of information about the physical and social anthropology of the indigenous Tasmanian, but also as a remarkable chapter in colonial history. To quote Plomley's apt comment about Robinson: "Usually humanity is a principle rather than a course of action. To find someone living up to his belief that all men are born equal but suffer from inequality of opportunity was and is extraordinary". Alas, all the good intentions of Robinson and certain other administrators only hastened final extinction.

Increased mortality resulting from early conflict with European settlers, and a decrease in births following the enslavement of numerous aboriginal women by the sealers, was followed by increasing mortality through Europeanintroduced diseases.

In addition to the journals, there are valuable extra sections and appendixes compiled by the editor. These review the prehistoric background, biological affinities and variation in the Tasmanians; also the distribution and names of the numerous small tribes. The appendixes also provide a geographical check-list of aboriginal and alternative European place names, a review of the natural history of the country, and a useful summary.

D. R. BROTHWELI

\section{MENTAL SET}

\section{The Psychology of Set}

By D. N. Uznadze. (The International Behavioral Science Series.) Pp. xvii +251. (New York: Consultants Bureau, 1966.) \$15.

THIs book appears in the International Behavioral Science Series, for which Dr. Joseph Wortis is the general editor. Other translations from the Russian in the same series are A. R. Luria's Higher Cortical Functions in Man (1966) and B. V. Andreev's Sleep Therapy in the Neuroses (1960).

Dmitrii Nikolaevich Uznadze (1886-1950) was for many years director of the Institute of Psychology of the Georgian Academy of Sciences in Tbilisi, where visitors today are hospitably received by Professor Prangishvili, one of his close collaborators and a former colleague. For many western readers, the first acquaintance with Uznadze's work probably came in the 1920 s through the pages of the German journal, Psychologische Forschung, which published articles deriving from the Gestalt school. Since then odd papers have appeared in proceedings of conferences and in a few western journals, but the present work is the first systematic presentation of the approach of Uznadze and the Georgian school to be available generally in the West. It comprises two monographs, Experimental Basis of the Psychology of Set, originally written in Russian, but first published in the Georgian language in 1949, and Basic Principles of the Theory of Set, also written in Russian, which has not hitherto been published.

The influence of a "mental set" has long been known. A common example is the way in which one "sees" or "hears" the approach of the expected visitor only to find that other stimuli have been biased or distorted by the pre-existing "set" of thought. The book deals with methods of establishing sets experimentally in visual, auditory and kinesthetic modalities. A set established for one hand can "irradiate" to the other, spontaneously, and so too, particularly with young children, sets may transfer from one sensory modality to another. Individuals differ appreciably in the readiness with which sets can be formed, retained and generalized to other situations. Quelitative stages in the extinction of a set, such as the "plastic", "coarse" or "inert" forms, are distinguished. Sets may be established in animals such as rats, chickens and chimpanzees, a field of work where a keen debate could develop between those who would prefer to use the language of the "set" theorists and others who would 